\title{
Tingkat Berpikir Geometri Siswa Kelas VII-B SMP Negeri 1 Jember Materi Segiempat Berdasarkan Teori van Hiele ditinjau dari Hasil Belajar Matematika

\author{
(The Level of Geometry's Thinking in VII-B SMP Negeri 1 Jember Material \\ Quadrilateral According Van Hiele Theory From Learning of Mathematics)
}

\author{
Mika Wahyuning Utami, Toto' Bara Setiawan, Ervin Oktavianingtyas \\ Program Studi Pendidikan Matematika, Jurusan PMIPA, FKIP, Universitas Jember (UNEJ) \\ Jln. Kalimantan 37, Jember 68121 \\ E-mail: totobara.fkip@unej.ac.id
}

\begin{abstract}
Abstrak
Tujuan dari penelitian ini untuk mendeskripsikan tingkat berpikir geometri siswa kelas VII-B SMP Negeri 1 Jember berdasarkan teori van Hiele yang ditinjau dari hasil belajar siswa. Jenis penelitian yang digunakan adalah penelitian deskriptif. Berdasarkan hasil analisis jawaban soal tes dan hasil wawancara diperoleh tingkat berpikir geometri van Hiele pada siswa kelas VII-B SMP N 1 Jember secara umum mencapai tingkat 3 yaitu deduksi, namun mayoritas siswa memiliki tingkat berpikir geometri van Hiele pada tingkat 2 yaitu deduksi informal. Siswa yang mencapai tingkat 3 . Siswa dengan hasil belajar tinggi dapat mencapai tingkat 3 sebanyak 4 siswa, tingkat 2 sebanyak 9 siswa, dan tingkat 1 sebanyak 2 siswa, sehingga siswa dengan hasil belajar tinggi cenderung memiliki tingkat berpikir van Hiele pada tingkat 2. Siswa dengan hasil belajar sedang dapat mencapai tingkat 3 sebanyak 1 siswa, tingkat 2 sebanyak 12 siswa, tingkat 1 sebanyak 1 siswa, dan tingkat 0 sebanyak 3 siswa, sehingga siswa dengan hasil belajar sedang cenderung memiliki tingkat berpikir van Hiele pada tingkat 2. Siswa dengan hasil belajar rendah dapat mencapai tingkat 2 sebanyak 1 siswa, tingkat 1 sebanyak 1 siswa, dan tingkat 0 sebanyak 1 siswa, sehingga siswa dengan hasil belajar rendah memiliki tingkat berpikir geometri van Hiele yang
\end{abstract} bervariasi.

Kata Kunci: Tingkat Berpikir Geometri, van Hiele, Segiempat, Hasil Belajar

\section{Abstract}

The purpose of this study to describe the level of thinking geometry class VII-B SMP Negeri 1 Jember by van Hiele theory that in terms of student learning outcomes. This type of research is descriptive research. Based on the results of the analysis of the answers to the tests and interviews obtained geometry van Hiele levels of thinking in students of class VII-B SMPN 1 Jember generally reach level 3 that deduction, but the majority of students have a geometry van Hiele levels of thinking on level 2 that informal deduction. Students who achieve level 3 students with high learning outcomes can reach as much as 4 students level 3, level 2 as much as 9 students, and level 1 as much as two students, so that students with learning outcomes tend to have a van Hiele levels of thinking on level 2. Students with learning outcomes are being able to achieve level 3 in 1 students, as many as 12 students' level 2, level 1 by 1 students, and the level of 0 for 3 students, so that students with moderate learning outcomes are likely to have the van Hiele levels of thinking on level 2. students with learning outcomes low can reach as much as 1 level 2 students, the rate of 1 in 1 students, and the level of 0 as 1 students, so that students with low learning outcomes have to think geometry van Hiele levels varied.

Keywords: Level Thinking Geometry, Van Hiele, rectangles, Learning Outcomes

\section{Pendahuluan}

Matematika sekolah menurut definisi resmi Depdiknas adalah matematika yang diajarkan di pendidikan dasar dan menengah [1]. Matematika sekolah terdiri dari empat kawasan yang luas salah satunya yaitu geometri. Peranan geometri dalam pelajaran matematika sangat kuat, bukan saja geometri yang membina proses berpikir, akan tetapi juga sangat mempengaruhi materi pelajaran lain dalam matematika. Untuk menyelesaikan masalah geometri, maka siswa harus terlebih dahulu memahami konsep atau sifatsifat dari geometri sehingga mudah dipahami dan tidak terjadi kesalahan. Agar konsep-konsep geometri dapat dipahami oleh siswa maka dapat menggunakan teori van
Hiele. Tahap-tahap pemahaman siswa dalam geometri menurut van Hiele ada 5 yaitu: tingkat 0 (visualisasi), tingkat 1 (analisis), tingkat 2 (deduksi informal), tingkat 3 (deduksi), tingkat 4 (rigor).

Pada tingkat 0 (visualisasi) siswa mengenal bentuk-bentuk geometri hanya sekedar berdasar karakteristik visual dan penampakannya. Pada tingkat 1(analisis) siswa dapat menentukan sifat-sifat suatu bangun dengan melakukan pengamatan, pengukuran, eksperimen, menggambar dan membuat model. Meskipun demikian, siswa belum sepenuhnya dapat menjelaskan hubungan antara sifat -sifat tersebut. Pada tingkat 2 (deduksi informal) siswa sudah dapat melihat hubungan sifat -sifat pada suatu bangun 
geometri dan sifat -sifat antar beberapa bangun geometri. Pada tingkat 3 (deduksi) siswa dapat menyusun bukti, tidak hanya sekedar menerima bukti. Pada tingkat 4 (Rigor) siswa bernalar secara formal dalam sistem matematika dan dapat menganalisis konsekuensi dari manipulasi aksioma dan definisi. Penelitian yang dilakukan oleh Burger dan Shaugnessy [2], dihasilkan data yang cukup untuk menyusun suatu indikator (karakteristik) tingkat-tingkat perkembangan berpikir geometri, namun penelitian tersebut hanya memberikan indikator untuk tigkat 0 sampai tingkat 3 .

Dalam tahap perkembangannya, peserta didik SMP berada pada tahap periode perkembangan Operasional formal (umur 11/12-18 tahun) [3]. Sehingga anak-anak diusia SMP atau kisaran usia 11/12-18 merupakan tahap perintisan atau awal pembelajaran menuju pelajaran yang lebih tinggi sehingga tahap perkembangan van Hiele pun masih belum ada yang mencapai level 4 yaitu level rigor. Penelitian yang berjudul "Mengembangkan Kemampuan Berpikir Geometris Pada Pokok Bahasan Segiempat Dengan Teori van Hiele dan Pendekatan PMRI" perkembangan tingkat berpikir geometris siswa di Sekolah Menengah Pertama jika dikaitkan dengan level berpikir geometris van Hiele, siswa hanya sampai pada level 3 yaitu deduktif informal [4]. Berdasarkan wawancara dengan guru matematika di SMP Negeri 1 Jember, siswa hanya mampu mengidentifikasi sifat-sifat persegi panjang, persegi, trapesium, jajargenjang, belah ketupat, dan layang-layang serta menghitung keliling dan luas segiempat serta penggunaannya dalam pemecahan masalah.

Berdasarkan kurikulum yang berlaku, materi segiempat yang diajarkan kepada siswa kelas VII meliputi persegi, persegipanjang, layang-layang, belahketupat, trapesium dan jajargenjang. Jika siswa tidak mengetahui konsep atau tidak memahami pembelajaran yang dilakukan oleh guru maka akan berpengaruh terhadap hasil belajar yang diperoleh oleh siswa. Hasil belajar siswa pada hakikatnya adalah perubahan tingkah laku sebagai hasil belajar dalam pengertian yang lebih luas mencakup bidang kognitif, afektif, dan psikomotorik [5].

Berdasarkan latar belakang yang diuraikan di atas maka perlu diadakan penelitian yang berjudul "Tingkat Berpikir Geometri Siswa SMP Negeri 1 Jember Kelas VII Materi Segiempat Berdasarkan Teori van Hiele ditinjau dari Hasil Belajar Matematika".

\section{Metode Penelitian}

Penelitian ini merupakan penelitian deskriptif. Penelitian deskriptif adalah penelitian yang dimaksudkan untuk menyelidiki keadaan, kondisi, atau hal lain-lain yang sudah disebutkan, yang hasilnya dipaparkan dalam bentuk laporan penelitian [6]. Penelitian deskriptif bertujuan untuk mendeskripsikan secara sistematik beberapa kenyataan dari sifat yang muncul secara faktual dan akurat [7]. Deskripsi yang dimaksud dalam penelitian ini adalah mengenai tingkat berpikir geometri siswa berdasarkan teori van Hiele ditinjau dari kemampuan matematika.

Pada penelitian ini dianalisis tingkat berpikir siswa SMP Negeri 1 Jember berdasarkan teori van Hiele materi segiempat ditinjau dari hasil belajar matematika siswa. Jadi pendeskripsian pada penelitian ini dilakukan dengan memberikan gambaran mengenai tingkat berpikir geometri siswa berdasarkan teori van Hiele.

Subjek penelitian pada penelitian ini adalah siswa kelas VII-B SMP Negeri 1 Jember. Untuk mempermudah dalam pelaksanaan penelitian, maka diperlukan alur penelitian dengan tahapan-tahapan sebagai berikut.

\section{a. Kegiatan Pendahuluan}

Kegiatan pendahuluan yang dilakukan dalam penelitian ini adalah menentukan daerah dan subjek penelitian, menyusun rancangan penelitian, membuat surat izin penelitian, dan berkoordinasi dengan Waka kurikulum dan guru matematika SMP Negeri 1 Jember untuk menentukan jadwal pelaksanaan penelitian dan validasi.

b. Pembuatan Instrumen

Pada tahap ini instrumen yang digunakan yaitu berupa tes uraian sebanyak 20 soal yaitu tiap level terdiri dari 5 soal. Level yang diteliti yaitu level 0 , level 1 , level 2 dan level 3. Pada penelitian ini peneliti akan menyusun pedoman wawancara untuk mendukung proses analisis tingkat berpikir geometri siswa. Pedoman wawancara digunakan agar pertanyaan yang diajukan tidak keluar dari topik pembicaraan.

c. Pengujian Validitas Tes Tingkat Berfikir van Hiele dan Pedoman Wawancara

Melakukan validasi tes tingkat berfikir van Hiele dan pedoman wawancara dengan cara memberikan lembar validasi kepada dua dosen Pendidikan Matematika Fakultas Keguruan dan Ilmu Pendidikan Universitas Jember dan seorang guru matematika SMPN 1 Jember.

d. Analisis Data Uji Validasi

Menganalisis data dari lembar validasi tes tingkat berfikir van Hiele dan pedoman wawancara. Apabila memenuhi kriteria valid maka dilanjutkan pada prosedur selanjutnya, namun jika tidak valid, maka dilakukan revisi dan uji validitas kembali.

e. Pengumpulan Data

Pengumpulan data diperoleh dengan melakukan tes, wawancara serta dokumentasi. Tes diberikan kepada siswa untuk mengetahui tingkat berpikir geometri siswa dalam menyelesaikan soal geometri pada pokok bahasan segiempat. Wawancara diberikan kepada siswa untuk memperkuat jawaban siswa dari hasil tes tingkat berpikir van Hiele. Dokumentasi siswa digunakan untuk melihat hasil belajar matematika siswa yaitu dari hasil 4 ulangan harian selama semester 2 tahun ajaran 2015/2016.

\section{f. Penganalisisan Data}

Pada tahap ini dilakukan analisis dari jawaban siswa atas soal tes yang telah diberikan dan akan dikelompokkan sesuai tingkat berpikir geometri. Pengelompokan siswa mengacu pada penskoran tes geometri van Hiele yang dikembangkan oleh Usiskin (1982) yaitu penerapan tingkat kelulusan sebesar. Dengan demikian untuk tingkat 0 karena ada 6 indikator maka siswa dikatakan mencapai level tersebut jika siswa memenuhi 4 indikator, untuk tingkat 1 dan tingkat 2 karena ada 8 indikator maka siswa dikatakan mencapai tingkat tersebut jika siswa memenuhi 5 indikator, dan untuk tingkat 3 karena ada 4 indikator maka siswa dikatakan mencapai tingkat 3 jika memenuhi 3 indikator. Siswa yang masuk pada level 2 atau level 
diatasnya maka siswa tersebut sudah melewati level sebelumnya. Misalkan siswa telah berada pada level 2 maka siswa tersebut sudah melewati level 0 dan level 1. Jika siswa gagal pada level tertentu maka siswa dianggap gagal dalam tingkat selanjutnya. Misalnya siswa hanya menjawab benar dengan memenuhi 3 indikator pada level 2 maka siswa dianggap gagal pada level 2 dan juga dianggap gagal pada level 3 dan hanya mencapai level 0 dan level 1.

g. Penyimpulan

Tahap ini merupakan tahap akhir dalam penelitian ini yaitu dengan penarikan kesimpulan atas rumusan masalah penelitian atau dengan kata lain pencapaian tujuan penelitian.

Instrumen penelitian yang digunakan pada penelitian ini yakni peneliti, soal tes tingkat berpikir van Hiele, pedoman wawancara, dan lembar validasi. Metode pengumpulan data yang digunakan dalam penelitian ini adalah metode tes, wawancara dan metode dokumentasi. Pada penelitian ini analisis yang digunakan adalah analisis deskriptif. Data yang terkumpul dalam penelitian deskriptif dapat diklasifikasikan menjadi data kualitatif dan kuantitatif. Data kualitatif dapat dijabarkan dengan kalimat yang dipisahkan menurut kategori untuk menarik kesimpulan. Data kuantitatif berupa angka Dari Tes Berfikir Geometri van Hiele yang diberikan pada 35 siswa kelas VII-B SMP Negeri 1 Jember dilakukan penilaian untuk mengelompokkan siswa pada/tingkat ketercapaiannya kemudian dari ulangan harian yang diberikan pada 35 siswa kelas VII-B SMP Negeri 1 Jember, dibutuhkan skor untuk memilih 9 siswa yaitu 3 siswa dari masing-masing tingkatan hasil belajar. Setelah didapat 9 siswa tersebut, dilakukan wawancara mengenai jawaban siswa dilakukan teknik analisis data.

Validitas yang digunakan adalah validitas isi dan validitas konstruksi. Sebuah tes dikatakan memiliki validitas isi (content validity) apabila mengukur tujuan khusus tertentu yang sejajar dengan materi atau isi pelajaran yang diberikan. Sebuah tes dikatakan memiliki validitas konstruksi (construct validity) apabila butir-butir soal yang membangun tes tersebut mengukur setiap aspek berpikir seperti yang disebutkan dalam Tujuan Instruksional Khusus. Dengan kata lain jika butir-butir soal mengukur aspek berpikir tersebut sudah sesuai dengan aspek berpikir yang menjadi tujuan instruksional. Validator memberikan penilaian terhadap tes tingkat berfikir geometri dan pedoman wawancara secara keseluruhan. Hasil penilaian yang telah diberikan ini disebut data hasil validasi dari tes tersebut, yang kemudian dimuat dalam tabel hasil validasi tes tingkat berfikir geometri dan pedoman wawancara. Berdasarkan nilai-nilai tersebut selanjutnya ditentukan nilai rata-rata total untuk semua aspek $(\mathrm{Va})$. Nilai $\mathrm{Va}$ ditentukan untuk melihat tingkat kevalidan tes tingkat berfikir geometri dan pedoman wawancara. Kegiatan penentuan $V a$ tersebut mengikuti langkah-langkah berikut.

1) hasil penilaian dimuat dalam tabel hasil validasi tes tingkat berfikir geometri dan pedoman wawancara, kemudian ditentukan rata-rata nilai hasil validasi dari semua validator untuk setiap aspek $\left(I_{i}\right)$. Menentukan rata-rata nilai hasil validasi dari semua validator untuk setiap indikator dengan rumus:

$$
I_{i}=\frac{\sum_{j=1}^{v} I_{i j}}{m}
$$

Keterangan:

$\mathrm{V} j i=$ data nilai ke- $j$ terhadap indikator ke- $i$

$\mathrm{n}=$ banyaknya validator

2) Dengan nilai $I_{i}$ kemudian ditentukan nilai rerata total pada setiap aspek $(\mathrm{V} a)$ dengan rumus:

$$
V_{a}=\frac{\sum_{i=1}^{n} I_{i}}{n}
$$

Keterangan:

$\mathrm{V} a=$ nilai rerata total untuk semua aspek

$I i=$ rerata nilai untuk aspek ke- $i$

$n=$ banyaknya aspek

Hasil Va yang diperoleh kemudian ditulis pada kolom yang sesuai. Selanjutnya nilai $V a$ atau rata-rata total ini dirujuk pada interval penentuan tingkat kevalidan model dan perangkat pembelajaran sebagai berikut [8]. Tabel 1 Kategori Tingkat Kevalidan

\begin{tabular}{|c|c|}
\hline Nilai $V a$ & Tingkat Kevalidan \\
\hline $1 \leq V a<2$ & Tidak valid \\
\hline $2 \leq V a<3$ & Kurang valid \\
$3 \leq V a<4$ & Cukup valid \\
$4 \leq V a<5$ & Valid \\
\hline$V a=5$ & Sangat Valid \\
\hline \\
Hasil dan Pembahasan
\end{tabular}

Berdasarkan hasil analisis data validasi tes dan validasi pedoman wawancara, diperolah tingkat kevalidan tes dan pedoman wawancara.

\section{1) Validasi Tes}

Tes soal tingkat berfikir geometri van Hiele yang digunakan berjumlah 5 butir soal untuk masing-masing tingkat yaitu tingkat $0,1,2$, dan 3 yang telah divalidasi oleh 3 validator yaitu 2 dosen ahli dari FKIP Universitas Jember dan 1 guru matematika SMP Negeri 1 Jember. Uji validitas digunakan untuk kevalidan soal dalam mencakup indikator yang diperlukan dalam tingkat berpikir geometri siswa dan untuk mengetahui kecocokan materi yang akan diujikan dengan materi yang diajarkan disekolah. Selanjutnya hasil validasi dari validator digunakan peneliti dalam menyusun soal tes tingkat berfikir geometri van Hiele. Skor instrumen tes tingkat berpikir van Hiele adalah 4.32 artinya instrumen tes dikatakan valid namun dengan beberapa saran revisi dari validator

2) Uji Validitas Pedoman Wawancara

Validitas pedoman wawancara dilakukan oleh 3 validator yaitu 2 dosen ahli dari FKIP Universitas Jember dan 1 guru matematika SMP Negeri 1 Jember untuk mengetahui kesesuaian pertanyaan yang hendak diberikan dengan data yang ingin diperoleh dalam penelitian. Skor instrumen 
pedoman wawancara adalah 4.12 artinya instrumen pedoman wawancara dikatakan valid namun dengan beberapa saran revisi dari validator

3) Hasil Tes Tingkat Berpikir van Hiele

a. Siswa dengan hasil belajar tinggi

Siswa B08, B26, B22, dan B34 telah menjawab dengan memenuhi lebih dari indikator untuk semua tingkat yaitu dari tingkat 0 sampai tingkat 3 sehingga siswa tersebut memiliki tingkat berpikir van Hiele pada tingkat 3 yaitu deduksi. Tingkat berpikir siswa tersebut menurut indikator sudah dapat menerima suatu pembuktian dan dapat menyederhanakan suatu pernyataan yang ambigu kebahasa yang lebih sederhana. Siswa tersebut juga sudah mampu menalar dan menjawab permasalahan yang diberikan hal tersebut sesuai dengan pendapat dari Kho yang menyebutkan bahwa pada tingkat ini siswa dapat menyusun bukti, tidak hanya sekedar menerima bukti [9]. Pada tingkat ini siswa berpeluang untuk mengembangkan bukti lebih dari satu cara.Siswa B11, B12, B14, B15, B18, B20, B21, B32, dan $\mathrm{B} 35$ telah menjawab dengan memenuhi indikator lebih dari untuk 3 tingkat yaitu dari tingkat 0 sampai tingkat 2 sehingga siswa tersebut memiliki tingkat berpikir van Hiele pada tingkat 2 yaitu deduksi informal. Tingkat berpikir siswa tingkat 2 atau tingkat deduksi informal sudah mampu menerima suatu definisi setiap benda geometri untuk mengklasifikasikan benda geometri dan mampu menerima logika parsial tentang sebuah benda hal tersebut/sesuai dengan pendapat dari Kho (dalam Siti: 2012) bahwa pada tingkat ini, siswa sudah dapat melihat hubungan sifat-sifat pada suatu bangun geometri dan sifat-sifat antara beberapa bangun geometri. Siswa B25 dan B33 mampu menjawab dengan memenuhi indikator lebih dari untuk 1 tingkat saja yaitu tingkat 0 sehingga siswa B25 dan B33 memiliki tingkat berpikir van Hiele pada tingkat 1 yaitu analisis. Pada tingkat ini siswa hanya mampu melihat benda secara umum tanpa melihat sifat-sifat benda dan hanya mengikuti apa yang telah diketahui sebelumnya tanpa bisa mengidentifikasi benda dan mendeskripsikan benda hal tersebut sesuai dengan pendapat dari Kho bahwa pada tingkat ini siswa mengenal bentuk-bentuk geometri hanya sekedar berdasar karakteristik visual dan penampakannya. Siswa secara eksplisit tidak terfokus pada sifat-sifat obyek yang diamati, tetapi memandang obyek sebagai keseluruhan.

\section{b. Siswa dengan hasil belajar sedang}

Siswa B02, B04, B06, B07, B09, B10, B13, B17, B19, B24, B27, dan B30 telah menjawab dengan memenuhi indikator lebih dari untuk 3 tingkat yaitu dari tingkat 0 sampai tingkat 2 sehingga siswa tersebut memiliki tingkat berpikir van Hiele pada tingkat yaitu deduksi informal. Tingkat berpikir siswa tingkat 2 atau tingkat deduksi informal sudah mampu menerima suatu definisi setiap benda geometri untuk mengklasifikasikan benda geometri dan mampu menerima logika parsial tentang sebuah benda hal tersebut sesuai dengan pendapat dari Kho bahwa pada tingkat ini, siswa sudah dapat melihat hubungan sifat-sifat pada suatu bangun geometri dan sifat-sifat antara beberapa bangun geometri. Siswa B03 telah menjawab dengan memenuhi lebih dari indikator untuk semua tingkat yaitu dari tingkat 0 sampai tingkat 3 sehingga siswa tersebut memiliki tingkat berpikir van Hiele pada tingkat 3 yaitu deduksi. Tingkat berpikir siswa tersebut sudah dapat menerima suatu pembuktian dan dapat menyederhanakan suatu pernyataan yang ambigu kebahasa yang lebih sederhana. Siswa tersebut juga sudah mampu menalar dan menjawab permasalahan yang diberikan hal tersebut sesuai dengan pendapat dari Kho yang menyebutkan bahwa pada tingkat ini siswa dapat menyusun bukti, tidak hanya sekedar menerima bukti. Pada tingkat ini siswa berpeluang untuk mengembangkan bukti lebih dari satu cara. Siswa B01 menjawab dengan memenuhi indikator lebih dari untuk 2 tingkat saja yaitu tingkat 0 dan tingkat 1 sehingga siswa tersebut memiliki tingkat berpikir van Hiele pada tingkat 1 yaitu analisis. Tingkat berpikir siswa sudah dapat membandingkan benda secara eksplisit dengan melihat sifat setiap komponen dan lebih membedakan benda secara umum saja hal tersebut sesuai dengan pendapat dari Kho yang menyebutkan bahwa Pada tingkat ini sudah tampak adanya analisis terhadap konsep dan sifat-sifatnya. Siswa dapat menentukan sifat-sifat suatu bangun dengan melakukan pengamatan, pengukuran, eksperimen, menggambar dan membuat model. Meskipun demikian, siswa belum sepenuhnya dapat menjelaskan hubungan antara sifat-sifat tersebut, belum dapat melihat hubungan antara beberapa bangun geometri dan definisi tidak dapat dipahami oleh siswa. Siswa B16, B23, dan B28 mampu menjawab dengan memenuhi indikator lebih dari untuk 1 tingkat saja yaitu tingkat 0 sehingga siswa tersebut memiliki tingkat berpikir yan Hiele pada tingkat 1 yaitu analisis. Pada tingkat ini siswa hanya mampu melihat benda secara umum tanpa melihat sifat-sifat benda dan hanya mengikuti apa yang telah diketahui sebelumnya tanpa bisa mengidentifikasi benda dan mendeskripsikan benda hal tersebut sesuai dengan pendapat dari Kho bahwa pada tingkat ini siswa mengenal bentukbentuk geometri hanya sekedar berdasar karakteristik visual dan penampakannya. Siswa secara eksplisit tidak terfokus pada sifat-sifat obyek yang diamati, tetapi memandang obyek sebagai keseluruhan.

c. Siswa dengan hasil belajar sedang

Siswa B05 menjawab dengan memenuhi indikator lebih dari untuk 2 tingkat saja yaitu tingkat 0 dan tingkat 1 sehingga siswa tersebut memiliki tingkat berpikir van Hiele pada tingkat 1 yaitu analisis. Tingkat berpikir siswa sudah dapat membandingkan benda secara eksplisit dengan melihat sifat setiap komponen dan lebih membedakan benda secara umum saja hal tersebut sesuai dengan pendapat dari Kho yang menyebutkan bahwa Pada tingkat ini sudah tampak adanya analisis terhadap konsep dan sifat-sifatnya. Siswa dapat menentukan sifat-sifat suatu bangun dengan melakukan pengamatan, pengukuran, eksperimen, menggambar dan membuat model. Meskipun demikian, siswa belum sepenuhnya dapat menjelaskan hubungan antara sifat-sifat tersebut, belum dapat melihat hubungan antara beberapa bangun geometri dan definisi tidak dapat dipahami oleh siswa. Siswa B31 telah menjawab dengan memenuhi indikator lebih dari untuk 3 tingkat yaitu dari tingkat 0 sampai tingkat 2 sehingga siswa tersebut memiliki tingkat berpikir van Hiele pada tingkat yaitu deduksi informal. Tingkat berpikir siswa tingkat 2 atau tingkat deduksi informal sudah mampu menerima suatu definisi setiap benda 
geometri untuk mengklasifikasikan benda geometri dan mampu menerima logika parsial tentang sebuah benda hal tersebut sesuai dengan pendapat dari Kho bahwa pada tingkat ini, siswa sudah dapat melihat hubungan sifat-sifat pada suatu bangun geometri dan sifat-sifat antara beberapa bangun geometri. Siswa B36 mampu menjawab dengan memenuhi indikator lebih dari untuk 1 tingkat saja yaitu tingkat 0 sehingga siswa B36 memiliki tingkat berpikir van Hiele pada tingkat 1 yaitu analisis. Pada tingkat ini siswa hanya mampu melihat benda secara umum tanpa melihat sifat-sifat benda dan hanya mengikuti apa yang telah diketahui sebelumnya tanpa bisa mengidentifikasi benda dan mendeskripsikan benda hal tersebut sesuai dengan pendapat dari Kho bahwa pada tingkat ini siswa mengenal bentukbentuk geometri hanya sekedar berdasar karakteristik visual dan penampakannya. Siswa secara eksplisit tidak terfokus pada sifat-sifat obyek yang diamati, tetapi memandang obyek sebagai keseluruhan.

\section{Kesimpulan dan Saran}

Berdasarkan hasil analisis dan pembahasan tentang tingkat berpikir geometri siswa SMP kelas VII-B SMP Negeri 1 Jember berdasarkan teori van Hiele ditinjau dari hasil belajar matematika, dapat diambil beberapa kesimpulan, yaitu diantaranya:

1) Mayoritas siswa memiliki tingkat berpikir geometri van Hiele pada tingkat 2 yaitu sebanyak 22 siswa sedangkan untuk tingkat 0 sebanyak 2 siswa, tingkat 1 sebanyak 8 siswa, dan tingkat 3 sebanyak 3 siswa.

2)Tingkat berpikir van hiele pada siswa SMP kelas VII-B SMP Negeri 1 Jember mencapai tingkat tertinggi yaitu tingkat 3 (deduksi).

3) Hasil belajar matematika siswa tinggi dan sedang dapat mencapai tingkat berpikir geometri van Hiele tingkat 3 sedangkan hasil belajar rendah hanya bisa mencapai tingkat berpikir geometri van Hiele tingkat 2.

4) Siswa dengan hasil belajar tinggi dapat mencapai tingkat 3 sebanyak 4 siswa, tingkat 2 sebanyak 9 siswa, dan tingkat 1 sebanyak 2 siswa, sehingga siswa dengan hasil belajar tinggi cenderung memiliki tingkat berpikir van Hiele pada tingkat 2.

5) Siswa dengan hasil belajar sedang dapat mencapai tingkat 3 sebanyak 1 siswa, tingkat 2 sebanyak 12 siswa, tingkat 1 sebanyak 1 siswa, dan tingkat 0 sebanyak 3 siswa, sehingga siswa dengan hasil belajar sedang cenderung memiliki tingkat berpikir van Hiele pada tingkat 2.

6) Siswa dengan hasil belajar rendah dapat mencapai tingkat 2 sebanyak 1 siswa, tingkat 1 sebanyak 1 siswa, dan tingkat 0 sebanyak 1 siswa, sehingga siswa dengan hasil belajar rendah memiliki tingkat berpikir geometri van Hiele yang bervariasi.

Berdasarkan hasil penelitian yang telah didapatkan, adapun beberapa saran yang bisa diberikan yakni sebagai berikut:

1) Bagi guru, diharapkan dapat lebih menekankan tentang definisi atau konsep tentang segiempat kepada siswa.

2) Bagi sekolah, hasil penelitian ini bisa dijadikan salah satu pertimbangan untuk mengetahui tingkat berpikir geometri van Hiele.
3) Bagi siswa, sebaiknya lebih memahami definisi segiempat sehingga jika ada soal yang berkaitan dengan definisi atau konsep bisa menjawab dengan baik.

4) Bagi peneliti lain, sebaiknya menggunakan instrument tes yang butir soalnya lebih sedikit namun dapat memenuhi indikator yang digunakan.

\section{Ucapan Terima Kasih}

Penulis mengucapkan terima kasih kepada Dosen Pembimbing, Validator, dan SMP Negeri 1 Jember yang telah membantu dalam penyelesaian tugas akhir ini.

\section{Daftar Pustaka}

[1] Suharno, 2004. Pendekatan Kooperatif dalam Pembelajaran Matematika ditinjau dari Kreativitas Siswa. Jurnal Penelitian Pendidikan UNS Surakarta: Teknodika . 2 (4)

[2] Hadiyan, Aris. 2007. Penelusuran Tingkat Siswa laki-laki dan perempuan pada materi segiempat. Tidak diterbitkan. Tesis. UNESA. Surabaya

[3] Budiningsih, Asri . 2005. Belajar Dan Pembelajaran. Jakarta : Rinekacipta

Wahyuni, dkk. 2014. Mengembangkan Kemampuan Berpikir Geometris Siswa pada Pokok Bahasan Segiempat dengan Teori Van Hiele dan Pendekatan Pendidikan Matematika Realistik Indonesia di Kelas VII SMP. Jakarta

[5] Sudjana, Nana. 1989. Penilaian Hasil Belajar Mengajar. Bandung: Sinar Baqru

[6] Arikunto, S. 2006. Prosedur Penelitian Suatu Pendekatan Praktik. Jakarta: Rineka Cipta

Sumiharsono, Rudy, 2009. Metodologi Penelitian. Jember: IKIP PGRI

[8] Hobri. 2010. Metodologi Penelitian Pengembangan. Pendidikan Matematika. Jember: Pena Salsabila

[9] Kurotul, Siti. 2012. Identifikasi Tingkat Berpikir Geometri Siswa Menurut Teori Van Hiele Ditinjau Dari Perbedaan Gender Pada Materi Pokok Segiempat (Studi Kasus Kelas VII SMPN 2 Gedangan). IAIN Sunan Ampel Surabaya 